\title{
Self-Interest and the Common Good in Book I of Homer's Iliad
}

\author{
by J. Fred Humphrey
}

If you recall Homers Iliad, you will remember that the poem, as we are often told, is the story of the Trojan War. The mythological background of the war is tied to a most unlikely sourcenamely, the judgment of Paris. All the gods and goddesses, according to the poets, with the exception Eris (the goddess of strife or discord), were invited to the wedding of Thetis and Peleus. When Eris tried to attend the celebration, she was turned away. To spite those who had denied her entrance, Eris tossed a golden apple inscribed with the words, To the Fairest, amongst the goddesses attending the wedding festivities. When Aphrodite, Athene, and Hera each claimed the honors for herself, Zeus was asked to settle the dispute, but the king of the gods was too clever to risk the wrath of two of the three goddesses by having to decide which one of three was indeed the fairest of them all. Instead, Zeus instructed Hermes to escort the three goddesses to Mount Ida where Paris, a young prince of the city of Troy and one of King Priams fifty sons, was tending his fathers flocks. Each goddess offered Paris gifts if only he would decide in her favor: Hera promised to make Paris a wealthy ruler of men who would control many lands; Athene promised the young prince physical strength so that he would become the strongest human being; and Aphrodite promised that he would wed Helen, the most beautiful of mortal women.[1] In the end, Paris accepted Aphrodites offer and chose love over political power and wealth or physical strength, and the rest, as people say, is history or mythology.

Here myth intersects legend, according to which Paris is sent as an emissary to the city of Sparta ruled by Atreus youngest son, Menelaus. Two lines of explanation are found in the tradition: one holds that Paris fell in love with Helen and she left for Troy with him of her own volition; the other maintains that Paris abducted Helen and she is forced to sail with him and his men to Troy. As Professor Hannah Arendt used to say, it all depends on whether you choose to think of Helen as a loose woman a whore or as a victim. Angered by the loss of Helen, Menelaus joins his brother Agamemnon to form an expedition ostensibly to return his wife to her rightful place in Sparta beside him. Agamemnon is chosen to lead the expedition and many able warriors and their armies are invited to join to share in the adventure and the plunder.

The war then, so the poets would have us believe, results directly from this sequence of events; however, the first book of the Iliad does not begin with them. Instead, we find ourselves on the shores of the city of Troy in the tenth year of the war. The poem begins with the word anger or rage (mënin).

Rage Goddess, sing the rage of Peleus son Achilles, Murderous, doomed, that cast the Achaens countless losses, hurling to the House of Death so many sturdy souls, great fighters souls, but made their bodies carrion, 
feasts for the dogs and birds, and the will of Zeus was moving toward its end.

Begin, Muse, when the two first broke and clashed.

Agamemnon lord of men and brilliant Achilles. (Fagles, Il. I, ll. 1-7, p. 77).[2]

While the poem appears to deal with the Trojan War, it has been argued that the real topic here is Achilleus anger. Indeed, in the Greek language anger is the first word of the entire work, and the rage referred to here belongs to Achilleus. For Achilleus is the one who quarrels with Agamemnon; Achilleus is the one who refuses to fight and prays for the demise of his fellow warriors until his own honor has been restored; Achilleus is the one who only returns to the battle to avenge the death of his friend, Patroklos; Achilleus is the one who kills Priams son, Hektor, in revenge for the death of Patroklos; and finally, Achilleus is the one who, consumed by his wrath, drags Hektors lifeless body up and down the plains of Troy until Priam begs for the return of his sons body so that he may prepare it for a proper burial. Indeed, Achilleus, the paradigmatic warrior, is the angry man.[3]

Those familiar with the poem, however, know all this. For the purposes of this reflection, I want to focus your attention on the first book of the Iliad and the quarrel between Agamemnon and Achilleus, and Nestors response to their disagreement. In particular, I would ask you to consider the tension between self-interest and the common good. While Achilleus is the one who first speaks for the common good, his commitment to the common good quickly disappears when his self-interest is threatened. Indeed, his understanding of his own self-interest leads Achilleus to undermine the common good. Agamemnon is much more complicated than Achilleus, for he does seem to realize that his self-interest and the common good are connected. To his credit, Agamemnon asserts his authority in service of the common good, but, unfortunately, Agamemnons attempts fail. In the end, he violates tradition on at least two important occasions, thus, indirectly causing the deaths of some of his soldiers and alienating his best warrior who refuses to fight for him. Regrettably, Agamemnons commitment to the common good appears to be a petty endorsement of his own self-interest. Like Achilleus and Agamemnon, Nestor speaks for the common good. He encourages the quarreling warriors, Achilleus and Agamemnon, to forget their grievances for the good of the entire coalition and he reminds them of that ancient principle: A house divided is easily defeated.

Let us begin, then, by considering the quarrel between Achilleus and Agamemnon. Since these passages are complicated, allow me to highlight some specific points. In a raid on several small communities outside of the gates of Troy, the armies have awarded Chryseis to Agamemnon as a prize of war; Achilles has been allotted Briseis. No doubt, such raids would have been necessary to supply the invading armies with necessities; each army was too far from its home to ship provisions. The quarrel referred to in the above citation from the first lines of the poem arises from Chryses a priest of Apollo and father of Chryseis coming to the Agamemnons camp to ransom his daughter. Agamemnon drives the old priest away and threatens his life should he ever return to the camp. While Agamemnon sends the old man away, it is interesting to note that the army encourages their leader to accept the ransom. Agamemnon, 
however, ignores their counsel.

After leaving Agamemnons camp in fear, Chryses prays to Apollo for the return of his daughter.

Hear me,

lord of the silver bow who set your power about Chryse

and Killa the sacrosanct, who are lord in strength over Tenedos,

Smintheus, if ever it pleased your heart that I built your temple,

if ever it pleased you that I burned all the rich thigh pieces

of bulls, of goats, then bring to pass this wish I pray for:

let your arrows make the Danaans pay for my tears shed. (Lattimore, ll. 36-42, p. 60).

Apollo hears Chryses prayer. The poet provides a wonderful, anthropomorphic description of some sort of plague caused by the god, Apollo, who strides angrily down from the pinnacles of Olympos, selects an arrow from his quiver, notches the bow, kneels on one knee, and lets fly with his arrow, killing first the mules and circling hounds, and then the men.

Achilleus first speaks for the common good, arguing that each army must return to its respective home because of the risks posed not only by the fighting, but now also by the additional dangers created by the plague. On the tenth day of the plague,

Achilleus calls an assembly, a war council, to ascertain the cause of the pestilence. Of course, if one wants to find the cause of such things, one only need ask one who knows a holy man, some prophet, or an interpreter of dreams. Kalchas, the best of the bird interpreters, rises to the occasion; he knows why Apollo is angry and he is willing to explain the gods wrath. He is willing to serve the common good the good for the entire coalition, but he also has a healthy sense of his own self-interest; Kalchas is interested in his own personal security. He knows that what he has to say will offend one stronger and more powerful than he is. He is willing to offer his services as a seer, but only if he receives protection. On receiving Achilleus promise to protect him from the wrath of anyone who might be offended by his insights into the cause of the plague, Kalchas, now free to speak, explains that the blame lies with King Agamemnon who has dishonored the priest, refused the ransom, and refused to return Chryseis the priests daughter.

When Kalchas has finished, Agamemnon launches into the seer, accusing him of being the barer of evil tidings; Kalchas is always the source of bad news. Agamemnon informs those assembled that he refused the ransom because he wished to have Chryseis in his own house since he liked her better than Klytaimestra his own wife. Nevertheless, he agrees to return his prize, if it is for the best. I desire, Agamemnon claims, that my people be safe, not perish (Lattimore, Il. I, ll. 116-17, p. 62). Finally, Agamemnon demands that he be granted another prize in place of Chryseis; he cannot be the only warrior to go without a prize. Again, Achilleus speaks for the common good; the distribution of the spoils of war has already been made; there are no more prizes in reserve to satisfy Agamemnons desires. Instead, Achilleus counsels Agamemnon to return Chryseis. To appease the god, Apollo, is most important and 
will work for the good of the entire coalition; and when Zeus hands the city of Troy to them to be plundered, the armies, Achilleus assures the King, will repay Agamemnon three or even four times over.

Achilleus has now twice spoken in support of the common good: once when he called the council to determine the cause of Apollos wrath in sending the plague and once when he counsels Agamemnon to return Chryseis. His devotion to the common good, however, quickly vanishes when Agamemnon threatens to take Achilleus prize Briseis. Faced with Agamemnons threat, Achilleus insults Agamemnon and accuses him of greed. He challenges Agamemnons leadership and argues that no one will want to fight for him. Achilleus maintains that although he does most of the fighting himself, he seldom receives rewards or recognition for his prowess in battle, while Agamemnon receives a greater share of the spoils of war. Furthermore, he observes that he has no quarrel with the Trojans because they have done nothing to him or his homeland in Phthia. Finally, he threatens to fight no more and return home with his ships and his Myrmidons. While Achilleus has twice spoken for the common good of the coalition, when Agamemnon challenges his honor by threatening to take his prize as a replacement for Chryseis, Achilleus quickly forgets the common good and defends what is his own. Three other factors demonstrate Achilleus lack of concern for the common good: First, Achilleus intends to kill Agamemnon and no doubt would have done so had Athene not intervened. Second, Achilleus leaves the battle and refuses to fight. Finally, he enlists his mother Thetis to seek Zeus assistance in avenging him by allowing the Trojans to kill his fellow warriors until Agamemnon recognizes the way in which he has harmed Achilleus and restores his honor. While this angry warrior appears to be concerned with the common good, his honor, i.e., his own individual self-interest, is most dear to him. Unfortunately, his investment in his own self-interest is so blind that he undermines the common good, which in the end ironically threatens his own security. For if Zeus does in fact help the Trojans defeat Agamemnon and his forces, the lives of Achilleus and his men will also be endangered.

Agamemnon mocks the angry Achilleus, encouraging him to follow his heart and leave like a coward; others will fight for him; he will not beg Achilleus to stay to fight. Besides, Achilleus is always arguing and quarrelling. Achilleus prowess as a warrior has nothing to do with his natural talents; according to Agamemnon, they are gifts of the god. As Achilleus reaches for his sword, intending to slay Agamemnon, the goddess, Hera, who loved both men equally sends Athene to stay Achilleus anger. Visible only to Achilleus, Athene prevents the angry warrior from completely drawing his sword from its scabbard; she tells him that he should not kill Agamemnon but that he may abuse the King with words. This Achilleus does, calling Agamemnon a wine sack, with a dogs eyes, with a deers heart (Lattimore, Il. I, 1. 225, p. 65), accusing him of cowardice and greed, and of being a King who feeds on his people who are nonenties (Lattimore, Il. I, 1. 231, p. 65). Achilleus concludes his angry diatribe against Agamemnon by swearing an oath on the scepter before the assembly. At some time in the near future, Achilleus warns, the coalition armies will face manslaughtering Hektor and they will regret having dishonored Achilleus, the best of the 
Achaians (Lattimore, Il. I, 1. 244, p. 65). Dashing the sceptre to the ground, Achilleus takes his seat.

Agamemnon, however, is a much more complicated character. From Achilleus angry words, it would be easy to assume that Agamemnon is indeed a selfish man who is only concerned with himself and his own self-interest. This, it seems to me, is a far too simplistic view of Agamemnons character. Agamemnon has been recognized by both human beings and the gods to be the King. Had he, for example, simply acquiesced and returned Chryseis to her father, he would have appeared weak before the armies. If he does not act to save face, would the armies respect him? Would they continue to follow orders and fight for him? If the warriors do not fight for him, would any of them return to their respective homes? Hence, Agamemnons selfinterest getting into the walled city of Troy, restoring his brothers wife Helen to her rightful place, plundering the city, and returning to his home safely and the interests of every other warrior are closely related. When Agamemnon asserts his authority as King, he acts for the common good. Without strong focused leadership, no one, including Agamemnon himself, will return from the plains of Troy. On the other hand, when Agamemnon refuses to return Chryseis to her father, he violates tradition. His actions are an affront to the god himself whose dissatisfaction with the King is reflected in the gods vengeance. It is fear of violating tradition and offending the god that lead the army to encourage Agamemnon to accept the ransom.

Agamemnon violates tradition a second time and for similar reasons. When he learns the causes of the plague from the seer, he must once again show that he is a leader capable of commanding the armies; he must return Chryseis to her father it is the only way to appease Apollo. At the same time, he must again assert his authority; to appear weak before the armies would make his leadership impossible. If the troops are to be successful, he must save face at all costs. To do otherwise would be to risk not only his own life, but also the lives of his soldiers. Hence, Agamemnon demands Achilleus prize Briseis. As Achilleus points out, however, the armies have already distributed the spoils of war; there is nothing to give Agamemnon to makeup for the loss of his prize. Agamemnons plan to take Achilleus prize is a violation of the distribution, a blatant violation of tradition. If Agamemnon asserts his authority to save face, he must also put Achilleus in his place; he cannot allow insubordination even from his most skillful warrior. In war, authority must be clearly defined; any hint of ambiguity will set a bad example, establish an unfortunate precedent, and send the wrong message to the other soldiers. Self-interest must be subordinated to the common good. In the end, however, Agamemnons efforts to assert his authority are only partially successful. He does not clearly distinguish his own individual selfinterest from the common good; since he sees that his self-interest is related to the common good, he believes he will attain the common good by arbitrarily asserting his authority and acting in his own interests. Instead, he violates the tradition, angers Apollo, and loses his most capable warrior. Indeed, he will return Chryseis to her father to appease Apollo; he will take Achilleus prize, Briseis; and he will continue to lead the armies. Achilleus, however, will leave the battle and refuse to fight until his honor is restored and Agamemnons failure to control Achilleus will lead to losses; he 
cannot win because his attempts to act for the common good, insult the god and anger Achilleus. His efforts to act for the common good make him appear to be selfserving in his actions. Indeed, Agamemnon is truly an individual who finds himself in a lose-lose situation; he cannot seem to win.

As Agamemnon and Achilleus hurl angry words, the aged Nestor of Pylos, who has joined the war to take the city of Troy not as a warrior, but as an advisor, rose to speak in kind intention toward both men (Lattimore, Il. I, 1. 253, p. 66). He has fought in past battles with better men than those by whom he now finds himself surrounded. Since warriors in glorious battles of the past have listened to him, Nestor counsels the two quarreling men to listen to him nowto listen to reason. Do you also obey, Nestor says to them, since to be persuaded is better (Lattimore, Il. I, 1. 274). Nestor speaks from the authority of reason grounded in tradition in virtue of his age and his experience. To both of them, Nestor exclaims:

Oh, for shame. Great sorrow comes on the land of Achaia.

Now might Priam and the sons of Priam in truth be happy, and all the rest of the Trojans be visited in their hearts with gladness, were they to hear all this wherein you two are quarrelling, you, who surpass all Dannaans in council, in fighting.

Yet be persuaded. Both of you are younger than I am (Lattimore, Il. I, ll. 254-58, p. 66).

Like Achilleus and Agamemnon, Nestor also speaks for the common good. Agamemnon and Achilleus strife would please their common enemy, King Priam of Troy and his sons; their disagreement would make all the Trojans happy. Nestor, then, appeals to the principle: A house divided is soon defeated. Only by being united in their efforts, only by embracing the common good, will they have any hope of success. Unlike Achilleus and Agamemnon, however, Nestor seems to be more aware of the consequences of infighting amongst the leaders of the various armies. To be sure, Nestor is not immediately threatened by Agamemnons desire to take his prize, but he does seem to understand that his self-interest staying alive in battle, acquiring wealth from plunder, and returning home to his loved ones is inextricably tied to the common good. Reason leads Nestor to embrace the common good as the only way to achieve his own self-interest. Thus, Nestor advises the two men to forget their grievances against one another in the name of the common good. To Agamemnon, he counsels: You, great man that you are, yet do not take the girl away but let her be a prize as the sons of the Achaians gave her first (Lattimore, Il. I, 1l. 275-77, p. 66). Nestor speaks appropriately as an advisor to King Agamemnon; he praises his greatness, but he also urges leniency. Agamemnon should honor the tradition; he should not violate the armies distribution of the spoils of war. Achilleus should keep his prize. Son of Atreus, give up your anger; even I entreat you to give over your bitterness against Achilleus, he who stands as a great bulwark of battle over all the Achaians (Lattimore, Il. I, ll. 282-84, p. 66). Additionally, Achilleus, he counsels, will prove useful in battle. Nestor quite clearly urges Agamemnon to be prudent and to consider the common good.

Similarly, Nestor exhorts Achilleus to overcome his bitterness toward Agamemnon 
and consider the greater good when he cautions:

Nor, son of Peleus, think to match your strength with the king, since never equal with the rest is the portion of honour of the sceptred king to whom Zeus gives magnificence. Even though you are the stronger man, and the mother who bore you was immortal, yet is this man greater who is lord over more than you rule. (Lattimore, Il. I, 277-80, p. 66).

Again, Nestor speaks appropriately as an advisor to the armies. He recognizes and praises the immortality of Achilleus mother Thetis, his superiority of birth, and his prowess in battle, but he also urges the warrior to recognize tradition and his place in that tradition. Achilleus may be the stronger and more able warrior, but Agamemnon is the legitimate ruler whose authority has been acknowledged by both human beings and the gods. Achilleus, too, must recognize and serve the King for the sake of the common good.

While Achilleus has twice spoken for the common good, he quickly forgets this concern when Agamemnon challenges his self-interest; Achilleus interest in the common good is quite superficial; he does not see his self-interest being tied to the common good. Indeed, self-interest in its most extreme form not only undermines the common good, but it also is self-defeating; ironically, extreme self-interest prevents Achilleus from realizing his own individual self-interest. Agamemnon is an individual who cannot hope to win. As a man, he wants to keep his prize; like Achilleus, he wants to be recognized, he wants to be honored. As the King, he must act for the common good. The Kings warriors and his soldiers must recognize his authority. If he fails in this, all is lost. His attempts to assert his authority, however, only achieve partial success because he fails to understand the distinction between the common good and his own individual self-interest and the proper relationship between the two. Nestor, on the other hand, sees his own self-interest as being bound up in the common good and advises both Agamemnon and Achilleus to be persuaded by reason to look beyond their own individual self-interest that leads them into conflict and consider the greater good so that they might achieve their common goal the destruction and the looting of the city of Troy. Unfortunately, neither Agamemnon nor Achilleus listen to Nestor.

While Nestor appears to be the one most concerned with the common good, his concern is extremely practical; he focuses on the immediate task to win glory in battle, to plunder the city of Troy, and to return safely to his home to rejoin his family and loved ones. Paradoxically, when Nestor appeals to the common good, he embraces a good that excludes the Trojans and their allies; he embraces a good that is good in relationship to himself and to his friendshis fellow warriors. Hence, while Nestors understanding of the common good may appear to be broader and more pragmatic than either Achilleus or Agamemnons, in fact he also, like Achilleus and Agamemnon, appeals to his own self-interest and the common good is defined in terms of his own self-interest. Unlike Achilleus, however, he recognizes that his own self-interest is unachievable unless Agamemnon acts appropriately as the king and leader of the expedition; unlike Agamemnon, he realizes that Achilleus is essential as 
a means to achieving his own self-interest and the common good, i.e., winning the war and looting the city of Troy. Agamemnon is aware of the importance of the common good, but who he is and the context in which he finds himself situated lead him to stumble in his attempt to assert his authority for the common good. Admittedly, Nestor is not in the same situation that Agamemnon finds himself; nor is he, unlike Achilleus, being asked to give up his prize. Hence, he is able to embrace the common good as he understands it without reservation, without compromising anything because, it is the way, perhaps the only way, for him to achieve his own selfinterest.

[1] Certainly, the poet attests to Helens beauty. See Il. III, 1l. 146-6o, p. 104, where the poet tells us that the elders who sat with Priam Panthos, Thymoites, Lampos, Klytios, and Hiketaon recognized Helens beauty.

Now those who sat with Priam: Panthos and Thymoites,

Lampos and Klytios, Hiketaon, scion of Ares,

with Antenor and Oukalegon, both men of good counsel:

these were seated by the Skaian gates, elders of the people.

Now through old age these fought no longer, yet were they excellent

speakers still, and clear, as cicadas who through the forest

settle on trees, to issue their delicate voice of singing.

Such were they who sat on the tower, chief men of the Trojans.

And these, as they saw Helen along the tower approaching, murmuring softly to each other uttered their winged words:

Surely there is no blame on Trojans and strong-greaved Achaians

if for long time they suffer hardship for a woman like this one.

Terrible is the likeness of her face to immortal goddesses. Still, though she be such, let her go away in the ships, lest

she be left behind, a grief to us and our children.

[2] Here I have used the Fagles translation because Fagles follows the Greek in so far as he begins with the word rage. However, in this essay unless otherwise noted, I will use The Iliad of Homer, translated and with an Introduction by Richmond Lattimore (Chicago, Illinois: University of Chicago Press, 1976). Lattimore renders this same passage as follows:

Sing, goddess, the anger of Peleus son Achilleus and its devastation, which put pains thousandfold upon the Achaians

hurled in their multitudes to the house of Hades strong souls of heroes, but gave their bodies to be the delicate feasting of dogs, of all birds, and the will of Zeus was accomplished since that time when first there stood in division of conflict Atreus son the lord of men and brilliant Achilleus. (Lattimore, Il. I, ll. 1-7, p. 59).

[3] If we think of Book IV of Platos Republic where Socrates distinguishes the three parts of the soul: reason, spiritedness, and desire, then Achilleus would be one who, according to the Socratic schema, is ruled by the spirited part of the soul. This, I believe, is critical for a proper understanding of Platos Apology of Socrates.

J. F. Humphrey is an assistant professor with a joint appointment in the North Carolina Agricultural and Technological State University, Department of Liberal Studies and the Division of University Studies. His research interests are in the history of philosophy. He has published articles in ancient philosophy, nineteenth century philosophy, and critical theory. He has also published a translation of Joan 


\section{Nordicum-Mediterraneum}

Stambaugh's dissertation entitled Untersuchungen zur Problem der Zeit bei Nietzsche under the title of The Problem of Time in Nietzsche. Humphrey has also compiled "A Bibliography of Works and Articles by and about Friedrich Nietzsche" (). 